\title{
A throughput serological Western blot system using whole virus lysate for the concomitant detection of antibodies against SARS- CoV-2 and human endemic Coronaviridae
}

Simon Fink ${ }^{1 \#}$, Felix Ruoff ${ }^{1 \#}$, Aaron Stahl ${ }^{1}$, Matthias Becker ${ }^{1}$, Philipp Kaiser ${ }^{1}$, Bjoern Traenkle ${ }^{2}$, Daniel Junker ${ }^{1}$, Frank Weise ${ }^{1}$, Natalia Ruetalo ${ }^{3}$, Sebastian Hörber ${ }^{4,5,6}$, Andreas Peter ${ }^{4,5,6}$, Annika Nelde ${ }^{7,8,9}$, Juliane Walz ${ }^{7,8,9,10}$, Gérard Krause ${ }^{11,12}$, Katja Schenke-Layland ${ }^{1,9,13,14}$, Thomas Joos ${ }^{1}$, Ulrich Rothbauer ${ }^{1,2}$, Nicole SchneiderhanMarra $^{1}$, Michael Schindler ${ }^{3}$, Markus F. Templin ${ }^{1 *}$

1 NMI Natural and Medical Sciences Institute at the University of Tübingen, Reutlingen,
Germany.
${ }^{2}$ Pharmaceutical Biotechnology, Eberhard-Karls-University, Tübingen, Germany.
${ }^{3}$ Institute for Medical Virology and Epidemiology of Viral Diseases, University Hospital
Tübingen, Tübingen, Germany.
${ }^{4}$ Central Laboratory, Institute for Clinical Chemistry and Pathobiochemistry, University Hospital Tübingen, Tübingen, Germany.

${ }^{5}$ Institute for Diabetes Research and Metabolic Diseases of the Helmholtz Center Munich at the University of Tübingen, Tübingen, Germany.

${ }^{6}$ German Center for Diabetes Research (DZD), München-Neuherberg, Germany.

${ }^{7}$ Clinical Collaboration Unit Translational Immunology, German Cancer Consortium (DKTK), Department of Internal Medicine, University Hospital Tübingen, Tübingen, Germany.

${ }^{8}$ Department of Immunology, Institute for Cell Biology, University of Tübingen, Tübingen, Germany.

${ }_{9}^{9}$ Cluster of Excellence iFIT (EXC2180) "Image-Guided and Functionally Instructed Tumor Therapies", University of Tübingen, Tübingen, Germany.

${ }^{10}$ Department of Hematology, Oncology, Clinical Immunology and Rheumatology, University Hospital Tübingen, Tübingen, Germany.

${ }^{11}$ Department of Epidemiology, Helmholtz Centre for Infection Research, Braunschweig, Germany.

12 TWINCORE GmbH, Centre for Experimental and Clinical Infection Research, a joint venture of the Hannover Medical School and the Helmholtz Centre for Infection Research, Hannover, Germany.

${ }^{13}$ Department of Women's Health, Research Institute for Women's Health, Eberhard-KarlsUniversity, Tübingen, Germany.

${ }^{14}$ Department of Medicine/Cardiology, Cardiovascular Research Laboratories, David Geffen School of Medicine at UCLA, Los Angeles, CA, USA.

\# These authors contributed equally to this work.

* Corresponding author:

Dr. Markus Templin

E-mail: templin@nmi.de

ORCID: 0000-0002-6569-6489

Keywords: endemic coronavirus, SARS-CoV-2, Western blot, DigiWest,

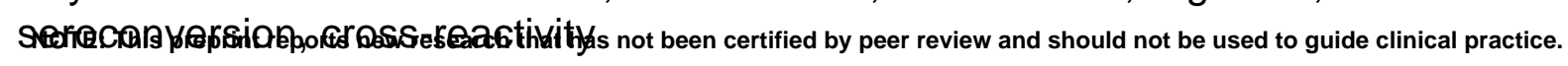


medRxiv preprint doi: https://doi.org/10.1101/2020.07.31.20165019; this version posted August 4, 2020. The copyright holder for this

\section{Abstract}

BACKGROUND: Seroreactivity against human endemic coronaviruses has been linked to disease severity after SARS-CoV-2 infection. Assays that are capable of concomitantly detecting antibodies against endemic coronaviridae such as OC43, 229E, NL63, and SARS-CoV-2 may help to elucidate this question. We set up a platform for serum-screening and developed a bead-based Western blot system, namely DigiWest, capable of running hundreds of assays using microgram amounts of protein prepared directly from different viruses.

METHODS: The parallelized and miniaturised DigiWest assay was adapted for detecting antibodies using whole protein extract prepared from isolated SARS-CoV-2 virus particles. After characterisation and optimization of the newly established test, whole virus lysates of OC43, 229E, and NL63 were integrated into the system.

RESULTS: The DigiWest-based immunoassay system for detection of SARS-CoV-2 specific antibodies shows a sensitivity of $87.2 \%$ and diagnostic specificity of $100 \%$. Concordance analysis with the SARS-CoV-2 immunoassays available by Roche, Siemens, and Euroimmun indicates a comparable assay performance (Cohen's Kappa ranging from $0.8799-0.9429$ ). In the multiplexed assay, antibodies against the endemic coronaviruses OC43, 229E, and NL63 were detected, displaying a high incidence of seroreactivity against these coronaviruses.

Conclusion: The DigiWest-based immunoassay, which uses authentic antigens from isolated virus particles, is capable of detecting individual serum responses against SARS-CoV-2 with high specificity and sensitivity in one multiplexed assay. It shows high concordance with other commercially available serologic assays. The DigiWest approach enables a concomitant detection of antibodies against different endemic coronaviruses and will help to elucidate the role of these possibly cross-reactive antibodies. 
medRxiv preprint doi: https://doi.org/10.1101/2020.07.31.20165019; this version posted August 4, 2020. The copyright holder for this

preprint (which was not certified by peer review) is the author/funder, who has granted medRxiv a license to display the preprint in

It is made available under a CC-BY-NC-ND 4.0 International license .

\section{Introduction}

Severe acute respiratory syndrome coronavirus 2 (SARS-CoV-2) is a newly identified beta coronavirus that crossed the species barrier and found its way into the human population in 2019. It causes the coronavirus disease 2019 (COVID-19), and the ongoing pandemic has a devastating effect on wide parts of the human population (1). The virus is highly contagious causing the disease to spread very rapidly, yet symptoms of infected individuals vary widely. A fraction of COVID-19 patients develops a fatal course of the disease, while mild COVID-19 cases are frequently observed (2). Different co-morbidity factors were recently identified, whereas the prediction of the course of the disease is not yet possible (3). Protective antibodies formed after infection are associated with viral clearance, but the occurrence of high antibody titres has also been linked to more serious forms of the disease (4). A role of pre-existing and cross-reacting antibodies, from endemic coronaviruses, that recognize proteins from SARS-CoV-2 is discussed and a phenomenon termed antibody-dependent enhancement (ADE), which is linked to existing antibodies, might be one of the reasons for life-threatening symptoms occurring during later stages of COVID-19 $(5,6)$.

An assay capable of detecting antibodies against endemic coronaviridae, such as OC43, 229E, and NL63, will help to understand a possible role of existing antibodies against these human coronaviruses during COVID-19. Available systems are using recombinant antigens to detect viral protein-directed antibodies in serum or plasma samples. This approach is not only economical but also makes the generation of large reagent batches feasible, allowing for the generation of vast numbers of assays required for systematic patient screening $(7,8)$. Here, we employ a novel way of building a serologic assay system to detect and characterise anti-SARS-CoV-2 
medRxiv preprint doi: https://doi.org/10.1101/2020.07.31.20165019; this version posted August 4, 2020. The copyright holder for this preprint (which was not certified by peer review) is the author/funder, who has granted medRxiv a license to display the preprint in It is made available under a CC-BY-NC-ND 4.0 International license .

antibodies. The approach utilised is based on the classical Western blot procedure, which has been modified to be run as a throughput assay system. The use of the complete pathogen proteome for antibody detection has been employed since the late 1970s (9) and subsequently proven to be useful for the identification of proteins recognized during the humoral immune response. In lysates, prepared from infectious virus particles, not only all possible viral proteins are present and can be probed in one assay, but the use of authentic antigens should enable the detection of antibodies recognising relevant protein modifications present in the naturally occurring pathogen.

The DigiWest procedure, which is employed here, is a variant of the classical Western blot. It addresses the most obvious disadvantages of Western blotting, namely its low throughput, high antigen consumption and poor reproducibility. In the DigiWest, the assay signal is generated on microspheres rather than on a membrane, thus allowing the use of fast and standardised assay protocols on the Luminex platform. Due to the inbuilt possibility of multiplexing, multiple antigens from different viruses can be probed at the same time, enabling the set-up of semiquantitative seroreactivity screens. 
medRxiv preprint doi: https://doi.org/10.1101/2020.07.31.20165019; this version posted August 4, 2020. The copyright holder for this

\section{Materials and Methods}

\section{Patients and blood samples}

A total of 263 pre-existing and de-identified serum samples was used for assay development. Ethical approval was granted from the Ethics Committee of University Hospital Tübingen; samples from 193 SARS-CoV-2 polymerase chain reaction (PCR) positive individuals (179/2020/BO2) and of 18 self-reported negative samples were collected (179/2020/BO2). A self-reported healthy serum sample $(n=1)$ and selfreported convalescent serum after SARS-CoV-2 infection $(n=2)$ were obtained at the NMI under the guidelines of the local ethics committees (495/2018/BO2). Sample collection for each donor was performed approximately three to eight weeks after the end of symptoms and / or negative virus smear. In addition, samples from healthy donors obtained from Central BioHub before 8/2019 were used as negative controls $(n=49)$

\section{SARS-CoV-2 virus lysate}

To prepare SARS-CoV-2 virus lysate, the supernatant of infected human Caco-2 cells was purified. Briefly, Caco-2 cells were infected 1:10 - 1:500 with clinical isolate 200325_Tü1. 48 hours post infection the supernatant was collected, centrifuged and frozen. $900 \mu \mathrm{L}$ of supernatant was added to $200 \mu \mathrm{L} 20 \%$ sucrose and centrifuged for 90 min at $4^{\circ} \mathrm{C}$ and $14000 \mathrm{rpm}$. The supernatant was discarded and a PBS washing step was done, followed by another centrifugation step. The supernatant was discarded and the viral pellet was re-suspended in $25 \mu \mathrm{L}$ of LDS sample buffer (Life Technologies) and heated for $5 \min$ at $95^{\circ} \mathrm{C}$.

\section{Multiplex serum reactivity test via DigiWest}


medRxiv preprint doi: https://doi.org/10.1101/2020.07.31.20165019; this version posted August 4, 2020. The copyright holder for this

preprint (which was not certified by peer review) is the author/funder, who has granted medRxiv a license to display the preprint in It is made available under a CC-BY-NC-ND 4.0 International license .

Whole viral protein lysates from 229E, OC43, and NL63 (ZeptoMetrix Corp) and from SARS-CoV-2 were used for DigiWest as described. Briefly, viral protein lysates were used for gel electrophoresis and Western blotting using the NuPAGE system.

Membranes were washed with PBST (0.1\% Tween-20, PBS) and membrane-bound proteins were biotinylated by adding $50 \mu \mathrm{M}$ NHS-PEG12-Biotin (Thermo Fisher Scientific) in PBST for $1 \mathrm{~h}$. After washing in PBST, membranes were dried overnight. Subsequently, the Western-Blot lanes were cut into 96 strips of $0.5 \mathrm{~mm}$ width and were transferred to a 96-well plate (Greiner Bio-One). For protein elution, $10 \mu \mathrm{L}$ of elution buffer was added to each well (8 M urea, 1\% Triton-X100 in 100 mM Tris-HCl $\mathrm{pH}$ 9.5) The protein eluates were diluted with $90 \mu \mathrm{L}$ dilution buffer (5\% BSA in PBST, $0.02 \%$ sodium azide). Neutravidin-coated MagPlex beads (Luminex) of a distinct colour ID were added to the protein eluates and binding was allowed overnight; 500 $\mu \mathrm{M}$ PEG12-biotin in PBST was added to block remaining Neutravidin binding sites. The bead containing fractions were pooled and thereby the original Western blot lanes were reconstituted. Beads were washed in PBST and resuspended in store buffer ( $1 \%$ BSA, $0.05 \%$ azide, PBS). The generated bead-set represents the proteomes of the four coronaviruses (SARS-CoV-2, OC43, 229E, NL63) and reactivity against all proteins can be tested in one assay.

For serum incubation, $5 \mu \mathrm{L}$ of the bead mix were equilibrated in $50 \mu \mathrm{L}$ serum assay buffer (Blocking Reagent for ELISA (Roche) supplemented with $0.2 \%$ milk powder, $0.05 \%$ Tween-20 and $0.02 \%$ sodium azide, $25 \%$ Low Cross buffer (Candor Bioscience), $25 \%$ IgM-reducing agent buffer (ImmunoChemistry). Serum assay buffer was discarded and $30 \mu \mathrm{L}$ of diluted patient serum (1:200 in serum assay buffer) was added and incubated for 2 hours at RT on a shaker. After washing in PBST, $30 \mu \mathrm{L}$ of Phycoerythrin labelled anti-human IgG secondary antibody (diluted 
medRxiv preprint doi: https://doi.org/10.1101/2020.07.31.20165019; this version posted August 4, 2020. The copyright holder for this preprint (which was not certified by peer review) is the author/funder, who has granted medRxiv a license to display the preprint in It is made available under a CC-BY-NC-ND 4.0 International license.

1:200 in serum assay buffer; Dianova) was added and incubated for 45 min at $23^{\circ} \mathrm{C}$. The beads were washed twice with PBST and readout was performed on a Luminex FlexMAP 3D.

The DigiWest analysis tool was used to assess serum reactivity against the viral proteins (10). Virus protein-specific peaks were identified and average fluorescence intensity (AFI) values were calculated by integration of peak areas.

To detect the nucleocapsid of SARS-CoV-2 a commercial antibody was used (Sino Biologicals; 40143-R019). Incubation was performed as described previously (11).

\section{Statistical analysis}

Sensitivity and specificity for each assay were calculated using the results of the PCR-testing as the gold standard. Concordance was calculated using Cohen's Kappa with $95 \%$ confidence intervals (CI) (12). Correlation was calculated using Spearman's $r$ with $95 \% \mathrm{Cl}$. For determining the dynamic range, a sigmoidal, 4-parameter logistic regression was used to fit the data and interpolate the dilution factor at the cut-off signal. All statistical analyses were performed using GraphPad Prism 8 or R studio (version 1.3.959). 
medRxiv preprint doi: https://doi.org/10.1101/2020.07.31.20165019; this version posted August 4, 2020. The copyright holder for this

\section{Results}

\section{DigiWest for detecting serum antibodies against SARS-CoV-2}

The DigiWest procedure is a variation of the Western blot that brings this classical approach into significantly higher throughput (9). Here, we used the method for size dependent separation of virus proteins reflecting the whole proteome and their subsequent immobilization on microspheres in order to adapt it to serum analysis. As a first step for detecting, serum antibodies recognizing viral proteins, lysates from infectious SARS-CoV-2 virus particles were prepared in SDS-PAGE loading buffer. DigiWest was performed as described using $0.5 \mu \mathrm{g}$ of virus protein and Luminex microspheres sufficient to run 100 assays were generated. Detection of total protein on the loaded DigiWest beads (Fig. 1A) showed characteristic protein bands for the lysate.

In the next step, human sera were diluted 1:200 in an optimized and modified serum assay buffer (see Materials and Methods) and incubated with the DigiWest microspheres. For SARS-CoV-2 negative samples, no or very low signals were obtained (Fig. 1D). High signals were detected from COVID-19 convalescent sera. Most sera showed their main peak of reactivity at $47 \mathrm{kDa}$, i.e. the size corresponding to the SARS-CoV-2 nucleocapsid protein (Fig. 1C). Using an antibody generated against the SARS-CoV-2 nucleocapsid, a prominent peak at $47.2 \mathrm{kDa}$ (Fig. 1B) was detected, which is consistent with the expected size of the protein. For a subset of serum samples, additional peaks corresponding to the spike protein are detected (Fig. 1E). Assay background was found to be variable, but since the determined signal intensities only consist of the peak area, reliable values were calculated using the DigiWest evaluation tool (10). Since reactivity against the nucleocapsid protein 
medRxiv preprint doi: https://doi.org/10.1101/2020.07.31.20165019; this version posted August 4, 2020. The copyright holder for this

preprint (which was not certified by peer review) is the author/funder, who has granted medRxiv a license to display the preprint in

It is made available under a CC-BY-NC-ND 4.0 International license

was consistently found in COVID-19 convalescent sera, these values were used for describing SARS-CoV-2 seroreactivity.

\section{Multiplexed DigiWest for detecting serum antibodies recognizing different human coronaviridae}

To expand the assay and to cover human endemic coronaviruses, virus lysates from the two alpha coronaviruses 229E and NL63 and from the beta coronavirus OC43 were processed as described above, and equivalent DigiWest assays were established and combined into one assay system. When using sera from SARS-CoV2 negative individuals, seroreactivity against viral proteins was found for a large fraction of tested samples. As for the SARS-CoV-2 DigiWest assay, the main serological activity for the different viruses was detected at a molecular weight that corresponds to nucleocapsid proteins. To prove that the detected proteins are indeed the nucleocapsids of the different coronaviruses, we produced recombinant versions of the nucleocapsid proteins of all tested viruses. We used the purified proteins in a different DigiWest experiment and compared the obtained signals with the signals obtained from the whole virus lysate DigiWest (Fig. 2A). In the whole virus lysate, the observed molecular weight of SARS-CoV-2 nucleocapsid protein was $47.2 \mathrm{kDa}$ with a calculated molecular weight of $45.6 \mathrm{kDa}$, for OC43 nucleocapsid protein it was $53.1 \mathrm{kDa}$ (calculated $49.3 \mathrm{kDa}$ ), for $229 \mathrm{E}$ nucleocapsid protein it was $45.4 \mathrm{kDa}$ (calculated $43.5 \mathrm{kDa}$ ) and for NL63 it was $42.1 \mathrm{kDa}$ (calculated $42.3 \mathrm{kDa}$ ) and thereby in good agreement with the expected values. The DigiWest using recombinant proteins (Fig. 2B) confirmed the molecular weights. A small set of 12 sera was used to detect seroreactivity on virus lysates and on the recombinant nucleocapsid proteins. Correlating signal was detected and this confirmed that the detected reactivity is directed against the nucleocapsid proteins. 
medRxiv preprint doi: https://doi.org/10.1101/2020.07.31.20165019; this version posted August 4, 2020. The copyright holder for this preprint (which was not certified by peer review) is the author/funder, who has granted medRxiv a license to display the preprint in

It is made available under a CC-BY-NC-ND 4.0 International license .

\section{Evaluation of the characteristics of the SARS-CoV-2 serological assay}

To characterize the performance of the DigiWest, we used the final multiplexed assay now comprising virus lysates of SARS-CoV-2, 229E, OC43 and NL63 to screen a set of characterized samples (13). Among the analyzed sera, there were 195 SARS-CoV-2 PCR positive specimens, 49 pre-pandemic samples and 19 selfreported negative samples. The complete data set, including a graphical representation of the assay signals in a Western-blot-like format, is available online in Supplemental Data 1. To define the assay cut-off for SARS-CoV-2 seropositivity, 68 non-infected control samples were employed. The highest signal value detected in this group was $1598 \mathrm{AFI}$. In a second step, the lowest value of all SARS-CoV-2 PCR-positive specimens still above this intensity (1968 AFI) was defined as a seropositive for SARS-CoV-2. The mean of these two measurements was calculated and defined to be the cutoff for seroconversion (1783 AFI). Using this value, an assay specificity of $100 \%$ was found. Furthermore, 26 / 195 (13.3\%) samples from SARS-CoV-2 PCR positive specimens showed no seroconversion, yielding a sensitivity of $87.2 \%$. These fundamental characteristics of the newly established assay system are comparable to published values for different commercially available SARS-CoV-2 immunoassays $(14,15)$.

To demonstrate the dynamic range of the serologic DigiWest assay, a SARS-CoV-2 positive serum was serially diluted with a negative serum (Fig. 3). Good signal linearity was seen in the dilution curve and seropositivity was detected down to a serum dilution of 1:5000.

For closer evaluation of the assay performance, we reanalyzed the complete sample set using the (i) Elecsys $\AA^{8}$ anti-SARS-CoV-2 assay (Roche Diagnostics), (ii) ADVIA Centaur® SARS-CoV-2 (Siemens Healthcare Diagnostics) (16), (iii) EUROIMMUN 
medRxiv preprint doi: https://doi.org/10.1101/2020.07.31.20165019; this version posted August 4, 2020. The copyright holder for this preprint (which was not certified by peer review) is the author/funder, who has granted medRxiv a license to display the preprint in It is made available under a CC-BY-NC-ND 4.0 International license.

SARS-CoV-2 IgG ELISA and (iv) EUROIMMUN SARS-CoV-2 IgA ELISA test systems. Further information on the assay procedures are provided in the Supplemental Data 2.

Concordance (Cohen's kappa) and Correlation (Spearman's r) analysis were performed and the different assay characteristics were compared and visualized (Fig.4A-D). Concordance of DigiWest vs Roche was found to be 0.9429 (95\% Cl; 0.90-0.98 Fig.4A) and for DigiWest vs Siemens, Cohen's kappa was 0.8860 (95\% $\mathrm{Cl}$; 0.83-0.94 Fig.4B). Concordance of DigiWest vs Euroimmun IgG was calculated in two ways: if the borderline results were considered positive, Cohen's kappa was found to be 0.9102 (95\% Cl; 0.86-0.96), if considered negative, the concordance was 0.8799 (95\% Cl; 0.82-0.94 Fig.4C). When comparing the DigiWest based IgG detection with the Euroimmun based $\lg A$ test and borderline results were considered positive, a value of $0.7498(95 \% \mathrm{Cl} ; 0.67-0.83)$ was found. If the borderline results were considered negative, Cohen's kappa was found to be $0.7518(95 \% \mathrm{Cl}$; 0.67 0.83).

Correlation analysis utilizing Spearman's $r$ revealed a positive correlation of all investigated assays (Fig. 4D). The highest correlation for DigiWest was found with the Roche system (Spearman's $r=0.91 ; 95 \% \mathrm{Cl}$; 0.89-0.93). Spearman's $r$ for DigiWest and Siemens was found to be 0.87 (95\% Cl; 0.83-0.90). Spearman's r for DigiWest and Euroimmun IgG and $\lg A$ was calculated at $0.87(95 \% \mathrm{Cl}$; 0.84-0.90) and $0.78(95 \% \mathrm{Cl} ; 0.72-0.82)$. The highest overall correlation was found between Siemens and Euroimmun IgG (Spearman's $r=0.94 ; 95 \% \mathrm{Cl} ; 0.92-0.96)$, the lowest overall correlation was found between Euroimmun $\operatorname{lgA}$ and Roche (Spearman's $r=$ $0.72 ; 95 \% \mathrm{Cl} ; 0.66-0.78)$. For the calculation of sensitivity and specificity, all assays 
medRxiv preprint doi: https://doi.org/10.1101/2020.07.31.20165019; this version posted August 4, 2020. The copyright holder for this preprint (which was not certified by peer review) is the author/funder, who has granted medRxiv a license to display the preprint in It is made available under a CC-BY-NC-ND 4.0 International license .

were compared based on the SARS-CoV-2 PCR status. The determined values for all employed systems are listed in Table 1.

\section{Multiplexed detection of antibodies against SARS-CoV-2, OC43, 229E and NL63}

By integrating DigiWest assays for 229E, OC43 and NL63 into the detection system for SARS-CoV-2, concomitant detection of the presence of antibodies binding to antigens derived from the different Coronaviridae becomes possible. In the analyzed sample set, reactive antibodies against all endemic coronaviruses were detected with high frequency (Supplemental Data 1). To estimate the reactivity against the other human endemic coronaviruses, a provisional cutoff for OC43, 229E and NL63 was defined at same value as determined for SARS-CoV-2 (1783 AFI). For Sars-CoV-2 negative sera, $82.4 \%$ showed reactivity against OC43 nucleocapsid, 95.6\% against 229E and $100 \%$ against NL63. For SARS-CoV-2 positive samples, the numbers were $79.5 \%$ against OC43, $99 \%$ against $229 \mathrm{E}$ and $98.5 \%$ against NL63. The overall reactivity was $80.2 \%$ against OC43, $98.1 \%$ against $229 \mathrm{E}$ and $98.9 \%$ against NL63. Despite the high frequency of antibodies directed against the endemic coronaviruses OC43, 229E, and NL63 in SARS-CoV-2 negative sera, no recognition of SARS-CoV-2 proteins was observed in these samples. This directly translates into the high specificity of the SARS-CoV-2 assay system and reveals that only minor or no cross-reactivity of existing antibodies with the SARS-CoV-2 nucleocapsid protein exists. The correlation analysis between all coronaviruses (including SARS-CoV-2) showed values ranging from 0.03 to 0.75 (Fig. 5). The highest correlation was observed for antibodies recognizing the nucleocapsid protein of $229 \mathrm{E}$ and NL63 with a Spearman's r of 0.75 indicating a possible cross-reactivity. 
medRxiv preprint doi: https://doi.org/10.1101/2020.07.31.20165019; this version posted August 4, 2020. The copyright holder for this

preprint (which was not certified by peer review) is the author/funder, who has granted medRxiv a license to display the preprint in

It is made available under a CC-BY-NC-ND 4.0 International license .

\section{Discussion}

The use of authentic proteins from clinically relevant pathogens as antigens for antibody detection is a classical method for identifying an individual immune response (17). While the approach has distinct drawbacks, e. g. the need for isolation of large amounts of pathogen and poor assay reproducibility when using different protein batches, it also provides substantial advantages. Modifications only found in the authentic proteins are present in antigen preparations and therefore the identification of reactive antibodies against these possible pathogen-derived antigens should be feasible. In addition, the generation of protein extract from pathogens of different strains is often technically uncomplicated and fast. This may turn out to be especially useful when a comparative analysis of antigen preparations from closely related pathogenic agents is of interest. Such an analysis may facilitate the identification of relevant cross-reacting antibodies directly on a wide variety of antigenic structures. These advantages may help to set up systems that take an unbiased approach to characterising the humoral immune response and may allow the identification of cross-reacting antibodies.

Here we describe the set-up of such an assay system using protein extracts prepared directly from infectious SARS-CoV-2 virus particles. The employed DigiWest procedure is an immunoblot system that closely resembles the classical Western blot procedure. After SDS-PAGE based protein size separation, proteins are immobilized on polystyrene microspheres and assay read-out is performed on the Luminex assay platform. 10 micrograms of protein are sufficient to generate batches of assay material for thousands of serum analyses; this directly translates into good assay reproducibility. In addition, the use of the Luminex platform for read-out allows for a high assay throughput without the need for producing recombinant proteins. As 
medRxiv preprint doi: https://doi.org/10.1101/2020.07.31.20165019; this version posted August 4, 2020. The copyright holder for this

preprint (which was not certified by peer review) is the author/funder, who has granted medRxiv a license to display the preprint in

It is made available under a CC-BY-NC-ND 4.0 International license .

in Western blotting, the assay gives direct information on the size of the recognized proteins, and often antigenic proteins can be directly identified. When using

COVID-19 convalescent sera, a specific antibody response to a protein of $47 \mathrm{kDa}$ corresponding to the nucleocapsid protein of SARS-CoV-2 was recurrently seen. Reactivity against other viral proteins was present in individual serum samples, yet the nucleocapsid protein was identified as the major antigen in this assay. The observed low seroreactivity against the spike protein is due to the fact that reduced and denatured proteins were employed for the DigiWest and that these protein forms are not recognized by most of the anti-spike antibodies (data not shown).

For the detailed evaluation of the performance of the newly developed assay for detecting anti SARS-CoV-2 antibodies a set of more than 250 well-characterized sera was employed, which were mainly taken from a clinical study on T-cell response after SARS-CoV-2 infection (13). By using 4 different serological assays that are in use in clinical routine labs we showed high concordance (Cohen's Kappa 0.88-0.94) between all systems. The detected specificity as compared to the PCR results was found to be ranging from $85.5 \%$ to $100 \%$, with the DigiWest, the Roche and the Siemens systems approaching $100 \%$. Sensitivity was found between $76.4 \%$ and $87.2 \%$, with the DigiWest reaching the highest score here. This demonstrates high standards for all tested assays. Interestingly, the highest concordance (0.94) was found between the Siemens assay system and the Euroimmun $\lg G$ assay, with both assays mainly detecting the spike protein. Nearly the same Kappa value was calculated for the Roche and the DigiWest system, both of which use the nucleocapsid protein as the detected antigen. The Euroimmun IgA showed slightly different assay characteristics, which is most likely due to the fact that it is the only 
medRxiv preprint doi: https://doi.org/10.1101/2020.07.31.20165019; this version posted August 4, 2020. The copyright holder for this preprint (which was not certified by peer review) is the author/funder, who has granted medRxiv a license to display the preprint in It is made available under a CC-BY-NC-ND 4.0 International license .

assay that exclusively detects IgA immunoglobulins. Yet, no principle differences in assay characteristics were observed and all assays showed high quality.

Antibodies against endemic coronaviruses are frequently found in human individuals (18). These viruses cause mild diseases and are associated with approximately $20 \%$ of the common colds $(19,20)$. However, when comparing the sequences of the virus genome, the degree of similarity between the SARS-CoV-2 and these viruses is astonishingly high (21). This similarity has led to speculations that antibodies against these endemic viruses may also possess protective properties against SARV-CoV-2 (22). The presence of these antibodies might explain the vastly diverse courses of disease. Therefore, the DigiWest assay system was expanded by using lysates from alpha coronaviruses 229E and NL63 as well as the beta coronaviruses OC43, thus enabling the detection of serum antibodies recognizing antigens from these four coronaviruses from one specimen in one assay. The implementation of these assays directly followed the method used for SARS-CoV-2 and seroreactivity against the nucleocapsid protein was frequently found for these coronaviruses.

As expected a very high rate of infection for all of the coronaviruses was found, yet no indication of cross-reactivity to the SARS-CoV-2 proteins was seen in prepandemic and other SARS-CoV-2 negative samples. This is in contrast to the described T-cell response that can be triggered by peptides derived from the SARS-CoV-2 nucleocapsid $(13,23)$.

Since the described assay was optimized for specificity, the employed assay conditions were highly stringent to avoid the occurrence of false positive signals. Modifications of the assay that use less stringent conditions assays could be used to detect cross-reactivity of antibodies formed against proteins from endemic 
medRxiv preprint doi: https://doi.org/10.1101/2020.07.31.20165019; this version posted August 4, 2020. The copyright holder for this preprint (which was not certified by peer review) is the author/funder, who has granted medRxiv a license to display the preprint in It is made available under a CC-BY-NC-ND 4.0 International license .

coronaviruses to SARS-CoV-2 viral proteins. This could give valuable information on the nature of these frequently found anti-corona antibodies; this work is ongoing.

As a serologic assay system the use of the DigiWest approach is not only novel, but it allows the set-up of a highly specific assay within a very short time frame and it is capable of detecting a wide variety of serum antibodies since all pathogen-derived proteins can be probed in one reaction. 
medRxiv preprint doi: https://doi.org/10.1101/2020.07.31.20165019; this version posted August 4, 2020. The copyright holder for this preprint (which was not certified by peer review) is the author/funder, who has granted medRxiv a license to display the preprint in It is made available under a CC-BY-NC-ND 4.0 International license .

\section{Author Contributions}

All authors confirmed they have contributed to the intellectual content of this paper and have met the following 4 requirements: (a) significant contributions to the conception and design, acquisition of data, or analysis and interpretation of data; (b) drafting or revising the article for intellectual content; (c) final approval of the published article; and (d) agreement to be accountable for all aspects of the article thus ensuring that questions related to the accuracy or integrity of any part of the article are appropriately investigated and resolved.

\section{Acknowledgement}

This work has received funding from the European Union's Horizon 2020 research and innovation program under grant agreement No 101003480 - CORESMA. 
medRxiv preprint doi: https://doi.org/10.1101/2020.07.31.20165019; this version posted August 4, 2020. The copyright holder for this preprint (which was not certified by peer review) is the author/funder, who has granted medRxiv a license to display the preprint in It is made available under a CC-BY-NC-ND 4.0 International license .

\section{References}

1. Wu F, Zhao S, Yu B, Chen YM, Wang W, Song ZG, et al. A new coronavirus associated with human respiratory disease in China. Nature. 2020;579:265-9.

2. Yang X, Yu Y, Xu J, Shu H, Xia J, Liu H, et al. Clinical course and outcomes of critically ill patients with SARS-CoV-2 pneumonia in Wuhan, China: a singlecentered, retrospective, observational study. Lancet Respir Med [Internet]. 2020;8:475-81. Available from:

https://linkinghub.elsevier.com/retrieve/pii/S2213260020300795

3. Rebello CJ, Kirwan JP, Greenway FL. Obesity, the most common comorbidity in SARS-CoV-2: is leptin the link? Int J Obes [Internet]. Springer US; 2020; Available from: http://dx.doi.org/10.1038/s41366-020-0640-5

4. Long Q-X, Tang X-J, Shi Q-L, Li Q, Deng H-J, Yuan J, et al. Clinical and immunological assessment of asymptomatic SARS-CoV-2 infections. Nat Med [Internet]. 2020; Available from: http://www.nature.com/articles/s41591-0200965-6

5. Arvin AM, Fink K, Schmid MA, Cathcart A, Spreafico R, Havenar-Daughton C, et al. A perspective on potential antibody-dependent enhancement of SARSCoV-2. Nature [Internet]. Springer US; 2020; Available from: http://dx.doi.org/10.1038/s41586-020-2538-8

6. Tetro JA. Is COVID-19 receiving ADE from other coronaviruses? Microbes Infect [Internet]. Elsevier Ltd; 2020;22:72-3. Available from: https://doi.org/10.1016/j.micinf.2020.02.006

7. Amanat F, Stadlbauer D, Strohmeier S, Nguyen THO, Chromikova V, McMahon $M$, et al. A serological assay to detect SARS-CoV-2 seroconversion in humans. Nat Med [Internet]. 2020;26:1033-6. Available from: http://www.nature.com/articles/s41591-020-0913-5

8. Becker M, Strengert M, Junker D, Kerrinnes T, Kaiser PD, Traenkle B, et al. Going beyond clinical routine in SARS-CoV-2 antibody testing - A multiplex corona virus antibody test for the evaluation of cross-reactivity to endemic coronavirus antigens. medRxiv [Internet]. 2020;2020.07.17.20156000.

Available from: 
medRxiv preprint doi: https://doi.org/10.1101/2020.07.31.20165019; this version posted August 4, 2020. The copyright holder for this preprint (which was not certified by peer review) is the author/funder, who has granted medRxiv a license to display the preprint in It is made available under a CC-BY-NC-ND 4.0 International license .

http://medrxiv.org/content/early/2020/07/17/2020.07.17.20156000.abstract

9. Burnette WN. "Western Blotting": Electrophoretic transfer of proteins from sodium dodecyl sulfate-polyacrylamide gels to unmodified nitrocellulose and radiographic detection with antibody and radioiodinated protein $A$. Anal Biochem [Internet]. 1981;112:195-203. Available from: https://linkinghub.elsevier.com/retrieve/pii/0003269781902815

10. Treindl F, Ruprecht B, Beiter Y, Schultz S, Döttinger A, Staebler A, et al. A bead-based western for high-throughput cellular signal transduction analyses. Nat Commun [Internet]. 2016;7:12852. Available from: http://www.nature.com/articles/ncomms12852

11. Treindl F, Zabinsky E, Kling S, Schwarz M, Braeuning A, Templin MF. Arraybased Western-blotting reveals spatial differences in hepatic signaling and metabolism following CAR activation. Arch Toxicol [Internet]. 2020;94:1265-78. Available from: http://link.springer.com/10.1007/s00204-020-02680-y

12. McHugh ML. Lessons in biostatistics interrater reliability : the kappa statistic. Biochem Medica [Internet]. 2012;22:276-82. Available from: https://hrcak.srce.hr/89395

13. Nelde A, Bilich T, Heitmann JS, Maringer $Y$, Salih HR, Roerden M, et al. SARS-CoV-2 T-cell epitopes define heterologous and COVID-19-induced Tcell recognition. Res Sq. 2020;

14. Tang MS, Hock KG, Logsdon NM, Hayes JE, Gronowski AM, Anderson NW, et al. Clinical Performance of Two SARS-CoV-2 Serologic Assays. Clin Chem [Internet]. 2020; Available from: https://academic.oup.com/clinchem/advancearticle/doi/10.1093/clinchem/hvaa120/5836557

15. Tang MS, Hock KG, Logsdon NM, Hayes JE, Gronowski AM, Anderson NW, et al. Clinical Performance of the Roche SARS-CoV-2 Serologic Assay. Clin Chem [Internet]. 2020; Available from: https://academic.oup.com/clinchem/advancearticle/doi/10.1093/clinchem/hvaa132/5850400

16. Hörber S, Soldo J, Relker L, Jürgens S, Guther J, Peter S, et al. Evaluation of three fully-automated SARS-CoV-2. Clin Chem Lab Med. 2020; 
medRxiv preprint doi: https://doi.org/10.1101/2020.07.31.20165019; this version posted August 4, 2020. The copyright holder for this preprint (which was not certified by peer review) is the author/funder, who has granted medRxiv a license to display the preprint in It is made available under a CC-BY-NC-ND 4.0 International license .

17. Leung DTM, Tam FCH, Ma CH, Chan PKS, Cheung JLK, Niu H, et al. Antibody Response of Patients with Severe Acute Respiratory Syndrome (SARS)

Targets the Viral Nucleocapsid. J Infect Dis [Internet]. 2004;190:379-86.

Available from: https://academic.oup.com/jid/article-lookup/doi/10.1086/422040

18. Sariol A, Perlman S. Lessons for COVID-19 immunity from other coronavirus infections. Immunity [Internet]. Elsevier Inc.; 2020; Available from: https://doi.org/10.1016/j.immuni.2020.07.005

19. Masse, S. Capai, L. Villechenaud, N. Blanchon, T. Charrel, R. Falchi A. Epidemiology and Clinical Symptoms Related to Seasonal Coronavirus Identified in Patients with. Viruses [Internet]. 2020;12:1-17. Available from: https://doi.org/10.3390/v12060630

20. Gorse GJ, Patel GB, Vitale JN, O'Connor TZ. Prevalence of antibodies to four human coronaviruses is lower in nasal secretions than in serum. Clin Vaccine Immunol. 2010;17:1875-80.

21. Wu A, Peng Y, Huang B, Ding X, Wang X, Niu P, et al. Genome Composition and Divergence of the Novel Coronavirus (2019-nCoV) Originating in China. Cell Host Microbe [Internet]. Elsevier Inc.; 2020;27:325-8. Available from: https://doi.org/10.1016/j.chom.2020.02.001

22. Nickbakhsh S, Ho A, Marques DFP, McMenamin J, Gunson RN, Murcia PR. Epidemiology of Seasonal Coronaviruses: Establishing the Context for the Emergence of Coronavirus Disease 2019. J Infect Dis [Internet]. 2020;222:1725. Available from: https://academic.oup.com/jid/article/222/1/17/5820656

23. Grifoni A, Weiskopf D, Ramirez SI, Mateus J, Dan JM, Moderbacher CR, et al. Targets of T Cell Responses to SARS-CoV-2 Coronavirus in Humans with COVID-19 Disease and Unexposed Individuals. Cell [Internet]. Elsevier Inc.; 2020;181:1489-1501.e15. Available from: https://doi.org/10.1016/j.cell.2020.05.015 
medRxiv preprint doi: https://doi.org/10.1101/2020.07.31.20165019; this version posted August 4, 2020. The copyright holder for this preprint (which was not certified by peer review) is the author/funder, who has granted medRxiv a license to display the preprint in It is made available under a CC-BY-NC-ND 4.0 International license .

\section{Supplemental Material}

Supplemental Material is available online. 
medRxiv preprint doi: https://doi.org/10.1101/2020.07.31.20165019; this version posted August 4, 2020. The copyright holder for this preprint (which was not certified by peer review) is the author/funder, who has granted medRxiv a license to display the preprint in It is made available under a CC-BY-NC-ND 4.0 International license .

\section{Figure legends}

Figure 1: Protein detection on SARS-CoV-2 virus lysate loaded DigiWest beads. Virus proteins were size separated by the Digiwest procedure and transferred to microspheres. In (A) a total protein stain of the separated proteins is shown; data are represented as Western-Blot mimic (10) thereby resembling a SDS-Page lane. The marked protein band corresponds to the viral nucleocapsid protein. An anti-SARSCoV-2 nucleocapsid antibody detects this protein at the expected molecular weight $(47.2 \mathrm{kDa})(B)$. Serum from a SARS-CoV-2 PCR positive patient reacts with the same protein (47.2 kDa) giving high fluorescent intensity $(\mathbf{C})$, whereas in a negative serum no peaks are detected (D). In a fraction of positive sera, additional peaks at $100 \mathrm{kDa}$ and $211 \mathrm{kDa}$ are detected (E, detailed view of $\mathbf{C}$ ).

\section{Figure 2: Multiplexed detection nucleocapsid protein from SARS-CoV-2, OC43,} 229E, and NL63. Reactivity of a patient serum was tested on whole virus lysates of the different coronavirus types (A) and on recombinant nucleocapsid proteins of the different viruses (B) using multiplexed DigiWest assays. The used SARS-CoV-2 positive serum shows antibody reactivity on whole virus lysates for (i) SARS-CoV-2, (ii) OC43, (iii) 229E, and (iv) NL63 (A). In (B) the same serum is incubated with a DigiWest bead-set loaded with recombinant nucleocapsid from (i) SARS-CoV-2, (ii) OC43, (iii) 229E, and (iv) NL63. As for the whole virus lysates antibody reactivity is observed; for SARS-CoV-2 a peak at 47.2 is kDa detected, for the endemic Coronaviridae OC43, 229E, and NL63 peaks at the molecular weights at the respective sizes of $53.1,45.4$ and $42.1 \mathrm{kDa}$ are found.

Figure 3: Dynamic range of the DigiWest serological assay. The serum of a SARS-CoV-2 positive patient was diluted in serum of a SARS-CoV-2 negative donor (serial dilution,13 steps ranging from 1:25 to 1:1131). The mixture was further diluted 1:200 in serum assay buffer and the immunoassay was performed. Shown are the final dilutions of positive serum (X-axis) and the resulting average fluorescence intensity (AFI). Logistic regression was performed using a sigmoidal fit and 4parameter logistics. (Bottom 110.0; Top 34406; IC50 2.962; HillSlope -1.411; log IC50 0.4716).

Figure 4: Comparison of the DigiWest seroconversion assay with commercially available SARS-CoV-2 assays. Concordance (Cohen's kappa) and correlation coefficients (Spearman's r) of DigiWest data and the commercially assays from 22 
medRxiv preprint doi: https://doi.org/10.1101/2020.07.31.20165019; this version posted August 4, 2020. The copyright holder for this preprint (which was not certified by peer review) is the author/funder, who has granted medRxiv a license to display the preprint in It is made available under a CC-BY-NC-ND 4.0 International license

Roche (A), Siemens (B) and Euroimmun IgG (C) were calculated and are shown below the plotted data; cutoff values are depicted as a black line in the scatter plot. For the Euroimmun IgG two different kappa values were calculated; when borderline results (as defined by the manufacturer) were considered positive, kappa was 0.9102. If the borderline results were considered negative, the concordance for Euroimmun IgG was 0.8799. In (D) the correlation coefficients (Spearman's r) between all used assays are shown in a heatmap. The highest value (Spearman's $r$ $=0.91$ ) for DigiWest was found for the Roche system, the lowest value (Spearman's $r$ $=0.78$ ) for DigiWest vs Euroimmun IgA shown of Spearman's r values.

Figure 5: Spearman's rank correlation of SARS-CoV2 and endemic coronavirus types in the serological DigiWest assay. Data generated for SARS-CoV-2, OC43, 229E and NL63 were used for correlation analysis and Spearman's rank coefficients were calculated for assay pairing. Results are displayed as heatmap of Spearman's $r$ values. A high correlation (Spearman's r 0.75) was found between NL63 and 229E indicating cross-reactivity.

Table 1: Sensitivity and Specificity for all employed assay systems

\begin{tabular}{|l|l|l|}
\hline Assay & Sensitivity & Specificity \\
\hline DigiWest & $87.2 \%$ & $100 \%$ \\
\hline Roche & $84.1 \%$ & $100 \%$ \\
\hline Siemens & $83.5 \%$ & $100 \%$ \\
\hline Euroimmun IgG cutoff negative & $80.0 \%$ & $100 \%$ \\
\hline Euroimmun IgG cutoff positive & $83.6 \%$ & $98.6 \%$ \\
\hline Euroimmun IgA cutoff negative & $76.4 \%$ & $89.9 \%$ \\
\hline Euroimmun IgA cutoff positive & $83.6 \%$ & $85.5 \%$ \\
\hline
\end{tabular}


A

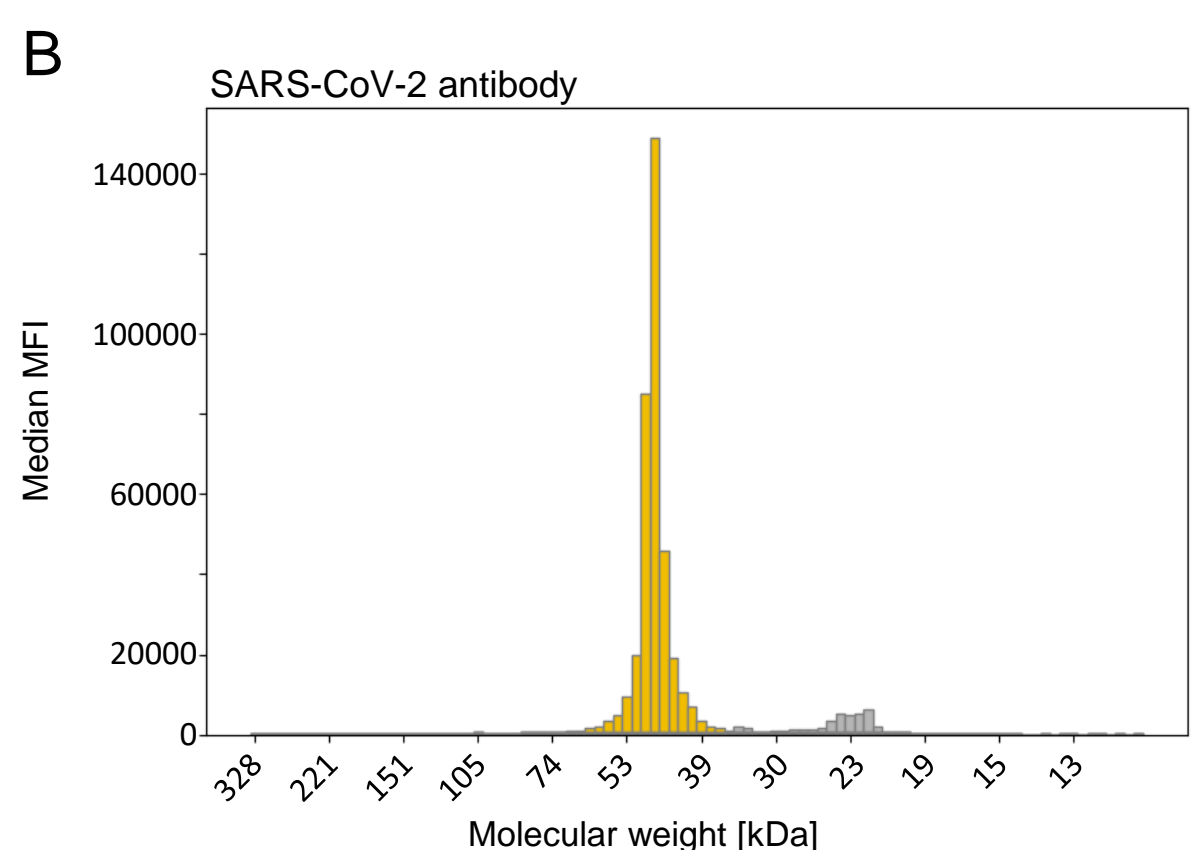

D

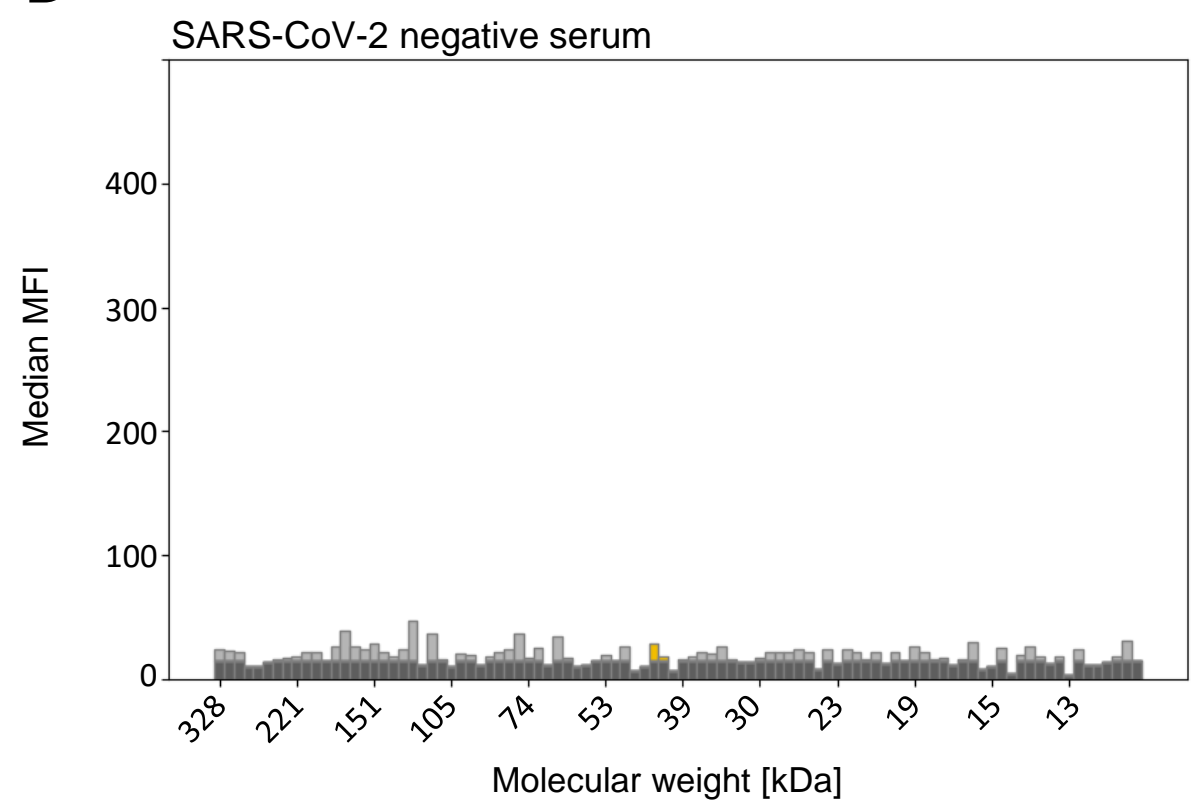

C

SARS-CoV-2 positive serum

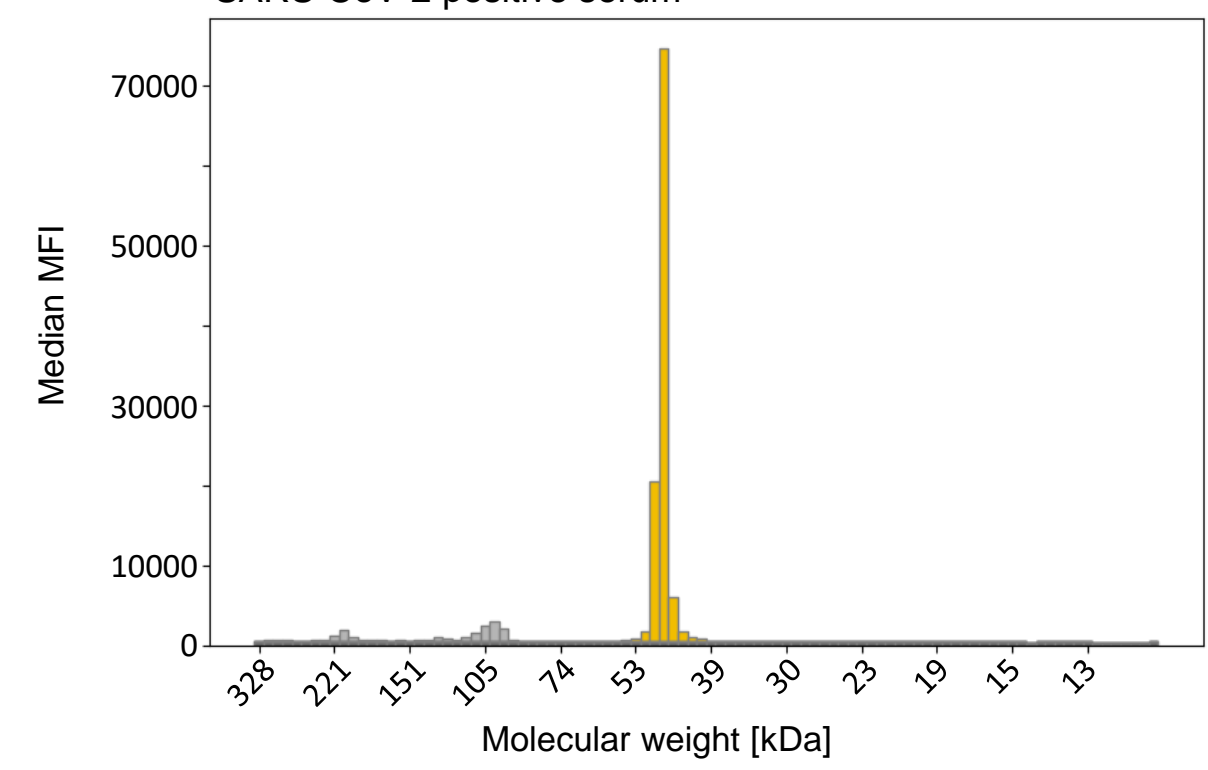

E

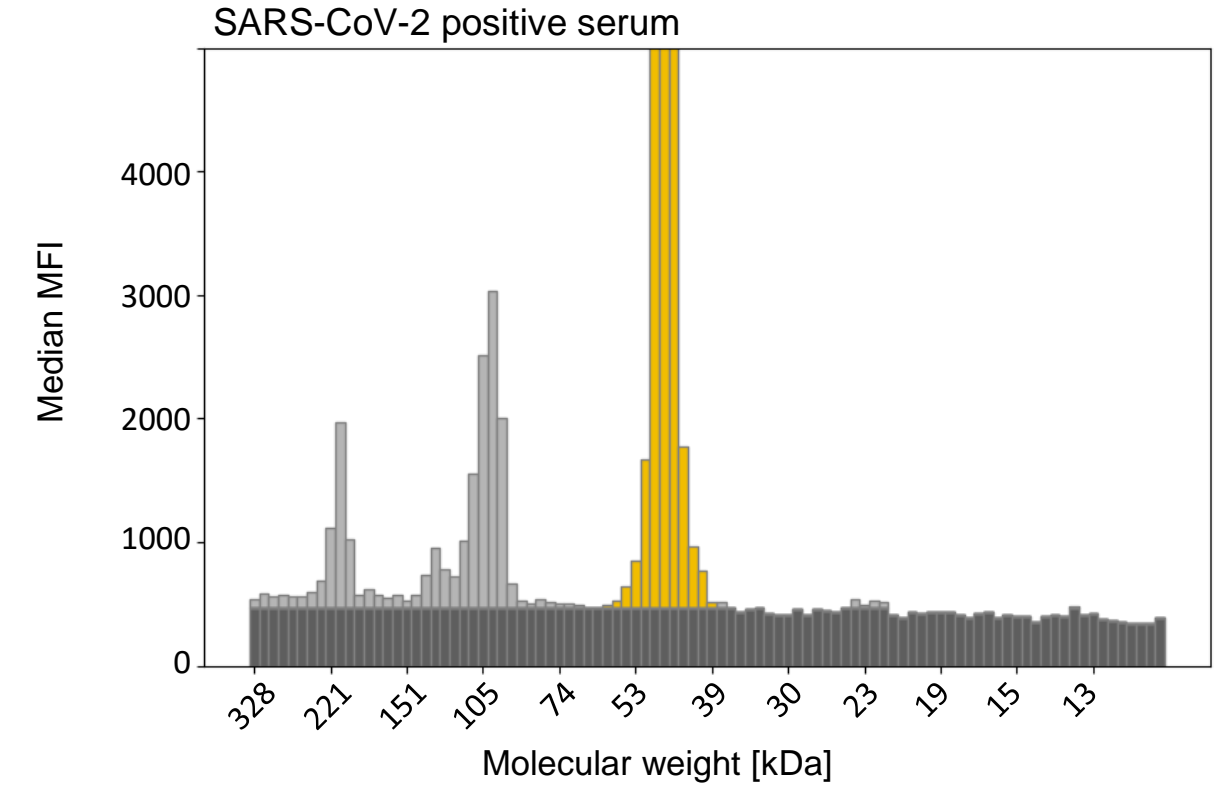




\section{Dynamic Range}

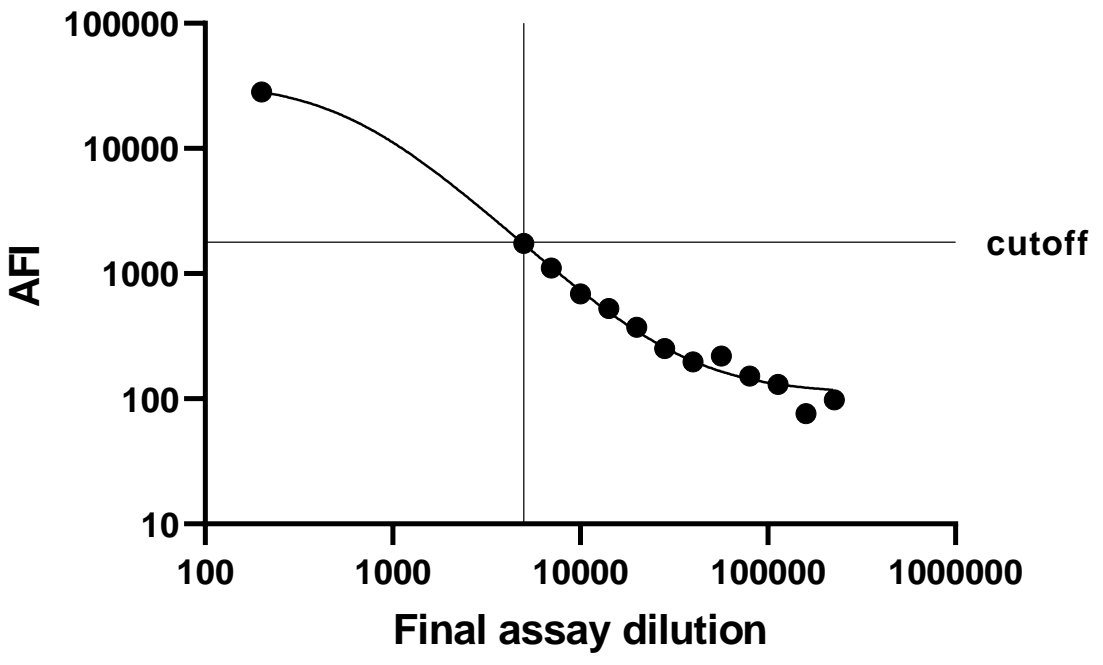


A

SARS-CoV-2 IgG DigiWest vs. Roche

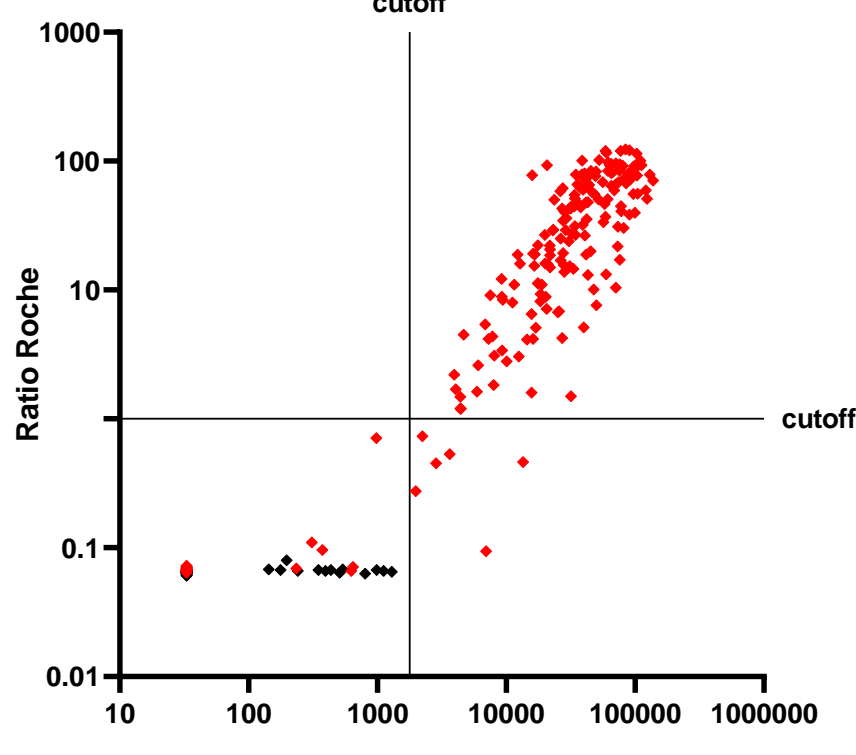

SARS-CoV-2 IgG Signal DigiWest [AFI]

Cohen`s kappa $=0.9429$

Spearman`s $r=0.9109$

positive $(n=195)$
negative $(n=68)$

C

SARS-CoV-2 IgG DigiWest vs. Euroimmun

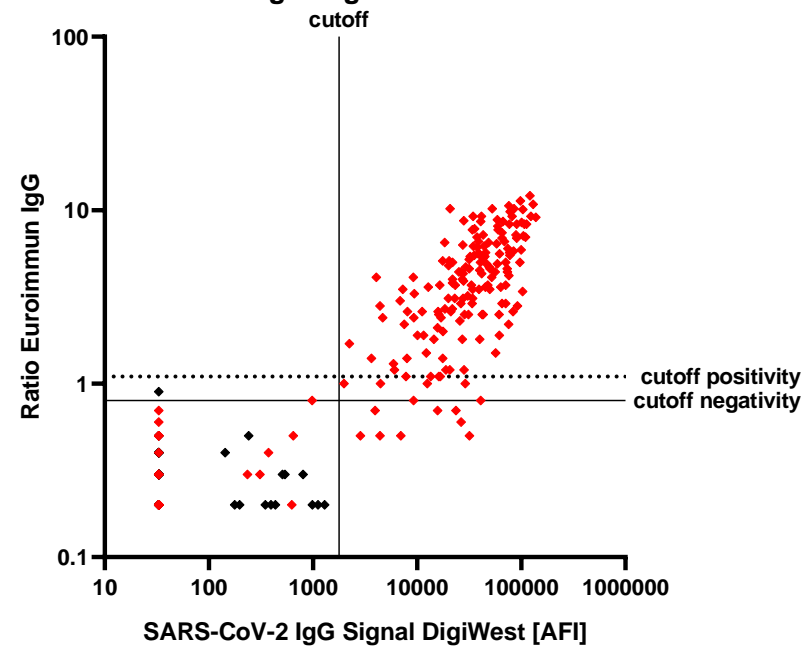

Cohen's kappa:

cutoff negativity $=0.8799$

cutoff positivity $=0.9102$

Spearman`s $r=0.8738$
B

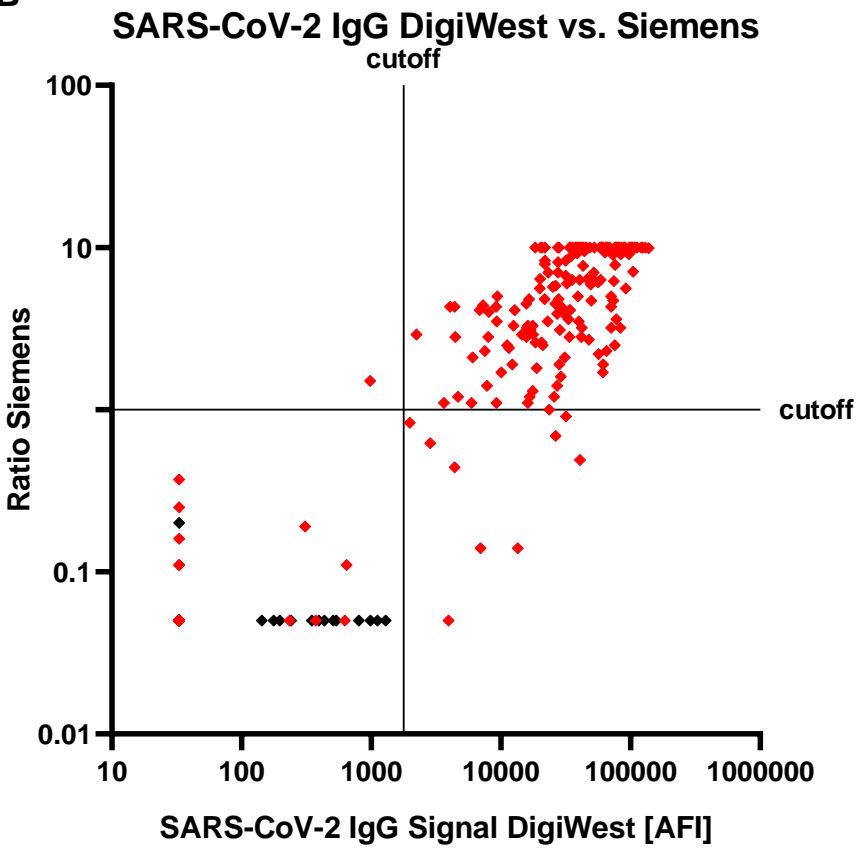

$\begin{array}{lll}\text { Cohen`s kappa }=0.8860 & \bullet & \text { positive }(\mathrm{n}=195) \\ \text { Spearman`s } r=0.8686 & \text { negative }(\mathrm{n}=68)\end{array}$

D

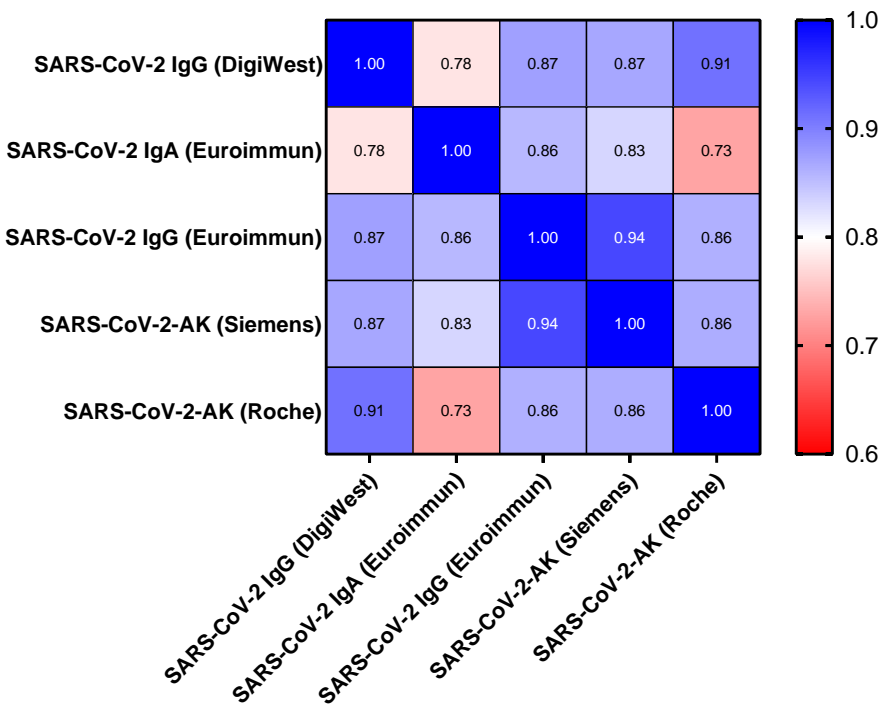




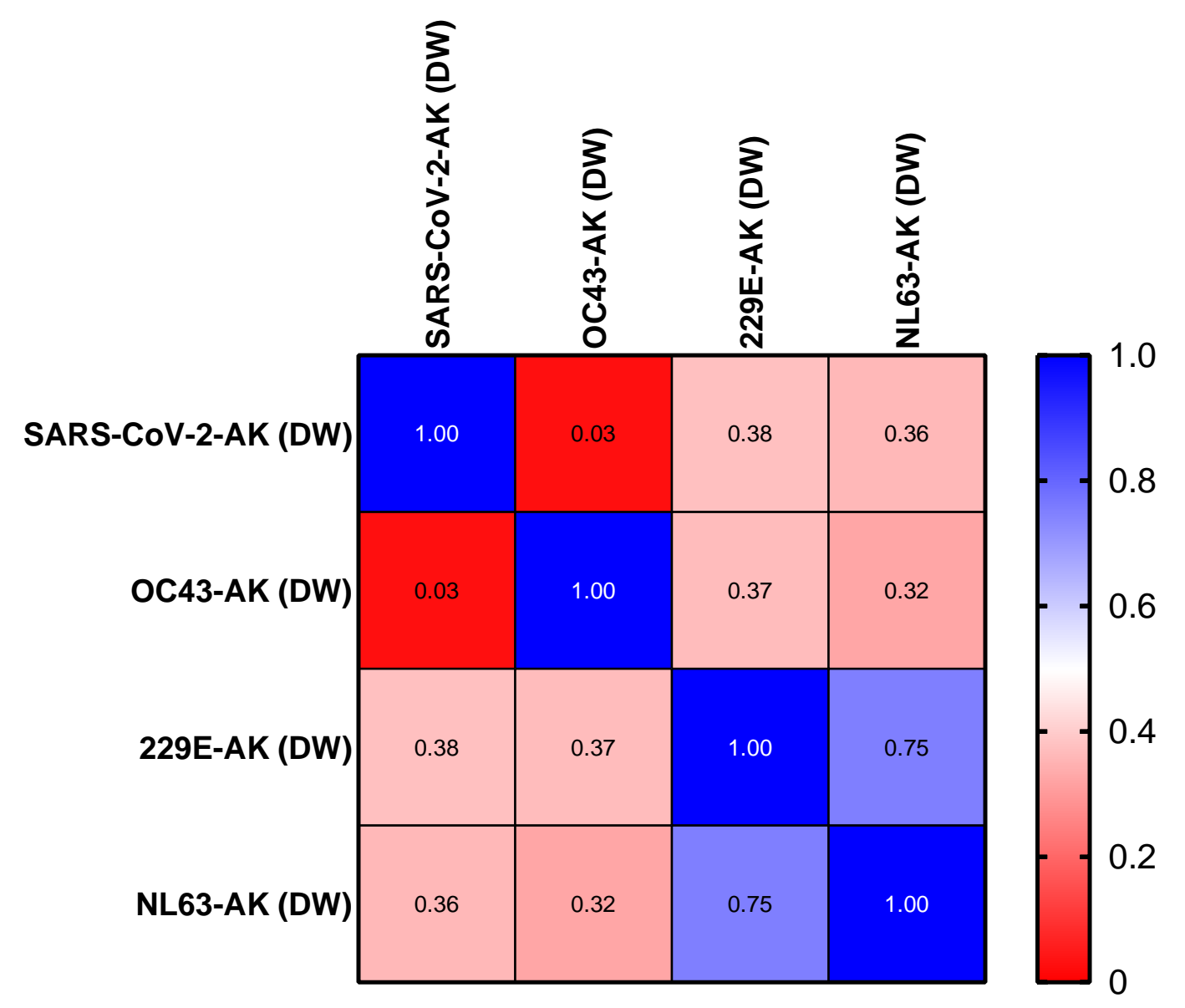

